\title{
Pengaruh Penambahan Kulit Kopi Kering Terhadap Penurunan Kadar Kafein Pada Kopi Lanang (Peaberry Coffee)
}

Ana Nur Imama, Rosyid ridho, Rika Endara Safitri

Program Studi Kimia, Fakultas Matematika dan Ilmu Pengetahuan Alam Universitas PGRI

Banyuwangi

Email korespondensi*: rosyidridho@gmail.com

September 2019

\begin{abstract}
ABSTRAK
Kopi merupakan minuman yang banyak digemari masyarakat luas, kopi mengandung kafein yang bisa membuat orang kecanduaan. Kafein dapat diturunkan dengan cara menambahkan kulit biji kopi terhadap kopi bubuk. Kulit kopi dapat menurunkan kadar kafein karena mengandung senyawa antioksidan. Analisyis kadar kafein pada kopi dengan variasi massa penambahan kulit biji kopi yaitu $(5,10,15,20,25 \%)$ terhadap 25 gram dan dilarutkan pada $100 \mathrm{~mL}$ Akuades dan 2 gram Natrium Karbonat $\left(\mathrm{Na}_{2} \mathrm{CO}_{3}\right)$ untuk mengikat zat tanin yang terlarut, ektrak dengan klorofom karena kafein mudah larut dalam kolorofom, titrasi dengan natrium thiosulfat hingga terjadi perubahan warna. Hasil penamambahan massa paling optimum adalah pada $25 \%$ yaitu dengan kadar kafein 0,0042. Analisis Penambahan 25\% massa kulit kopi terhadap 25 gram kopi dengan variasi suhu seduh pelarut yaitu $\left(60,70,80,90,100{ }^{\circ} \mathrm{C}\right)$. hasil dari perlakuan variasi suhu seduh yang paling optimum adalah pada suhu 90-96 ${ }^{\circ} \mathrm{C}$ karena suhu air paling baik dalam membuat kopi, dari suhu optimum kadar kafein adalah 0,0044. pH yang terkandung dalam 25\% penambahan kulit kopi terhadap 25 gram kopi lanang adalah 5,5 yang artinya kopi layak dikonsumsi dan dari 10 panelis menyukai kopi ini karna rasanya sama dengan kopi tanpa penambahan kulit kopi tersebut. Pada Penelitian ini menggunakan metode titrasi ektraksi klorofoms.
\end{abstract}

Kata Kunci : kulit biji Kopi kering penuruanan kadar kafein,Kopi Lanang (Peaberry caffe)

ISSN 2685-7065 
Kopi merupakan salah satu jenis tanaman perkebunan yang sudah lama dan dibudidayakan dan memiliki nilai ekonomis yang tinggi. Konsumsi kopi dunia mencapai $70 \%$ berasal dari spesies arabika dan $26 \%$ kopi robusta. Kopi mempunyai nama latin Coffea Sp. Buah kopi terdiri dari 4 bagian yaitu lapisan kulit luar (exocarp),daging buah (mesocarp), kulit tanduk (parchment), biji (endosperm). Indonesia menempati urutan keempat sebagai penghasil kopi terbanyak di dunia. Kopi merupakan hasil komoditi perkebunan yang memiliki nilai ekonomis yang cukup tinggi di antara tanaman perkebunan lainnya dan berperan penting sebagi sumber devisa negara. Salah satu kandungan senyawa dalam kopi adalah kafein.

Kopi merupakan minuman yang banyak digemari masyarakat luas dari berbagai kalangan. Saat ini pula, kopi merupakan minuman terbesar kedua yang dikonsumsi orang di seluruh dunia, setelah air (Sofiana, 2011). Penikmat Kopi biasanya meminum kopi 3-4 kali dalam satu hari (Maramis, dkk., 2013). Kopi memiliki banyak manfaat bagi kesehatan jika digunakan dalam batas wajar, seperti mengurangi derita sakit kepala, aroma kopi menghilangkan stress, kafein kopi mencegah gigi berlubang, melegakan penderita asma, memperkaya antioksidan tubuh, melindungi kulit, mencegah penyakit parkinson, merangsang kerja otak, dan lain-lain (Sofiana, 2011).

Masalah utama dari mengkonsumsi kopi adalah kadar kafein yang terkandung di dalamnya (Mulato, 2001). Kafein memiliki efek farmakologis yang bermanfaat secara klinis, seperti menstimulasi susunan syaraf pusat, dengan efek menghilangkan rasa letih, lapar dan mengantuk, juga meningkatkan daya konsentrasi dan kecepatan reaksi, memperbaiki kerja otak dan suasana jiwa, serta memperkuat kontraksi jantung. Penggunaan kafein secara berlebihan dapat menimbulkan debar jantung, gangguan lambung, tangan gemetar, gelisah, ingatan berkurang, dan sukar tidur (Tjay dan Rahardja, 2007). Pada kondisi tubuh yang normal memang memiliki beberapa khasiat antara lain merupakan obat analgetik yang mampu menurunkan rasa sakit dan mengurangi demam. Akan tetapi, pada tubuh yang mempunyai masalah dengan keberadaan hormone metabolisme asam urat, maka kandungan kafein dalam tubuh akan memicu terbentuknya asam urat tinggi.

Kafein adalah senyawa alkaloid turunan xantine (basa Purin) yang secara alami banyak terdapat pada kopi. Pada biji kopi kafein yang terkandung berkisar1-2,5\%. Pada satu cangkir kopi dalam $100 \mathrm{ml}$ mengandung 80-100 mg kafein, tergantung dari banyaknya kopi yang digunakan (Tjay dan Rahardja, 2007). 
Kopi robusta merupakan keturunan dari beberapa jenis kopi.Kopi robusta mempunyai dua jenis biji yaitu kopi yang berbiji dua dan berbiji satu, kopi yang berbiji satu yaitu disebut kopi lanang.kopi lanang banyak di produksi di perkebunan (Lerek,Gombengsari, Banyuwangi) dengan kondisi alam dan suhu udara yang sangat dingin. Kopi lanang ini banyak dikonsumsi masyarakat daerah Banyuwangi.Dari hasil penelitian kopi lanang banyak mengandung kafein dibandingkan jenis kopi yang lain. Kopi juga tanaman yang menghasilkan limbah hasil sampingan yang cukup besar dari hasil pengolahan. Limbah sampingan tersebut berupa kulit kopi yang jumlahnya berkisar antara 50 - 60 persen dari hasil panen. Limbah kulit kopi belum dimanfaatkan petani secara optimal. Berdasarkan hal ini kami ingin memanfaatkan limbah kulit kopi untuk menurunkan kadar kafein pada kopi lanang, karena dari limbah kulit biji kopi tersebut mengandung senyawa antioksidan. Kami ingin membuat kopi lanang menjadi hasil produk pertanian yang mudah dikonsumsi tanpa memberikan limbah dan juga baik untuk kesehatan bagi yang mempunyai penyakit tertentu tapi ingin mengkonsumsi kopi lanang.Penelitian ini bertujuan untuk mempelajari pengaruh penambahan kulit kopi terhadap penurunan kadar kafein terhadap bubuk biji kopi lanang.

\section{METODE PENELITIAN}

Alat yang digunakan dalam penelitian ini meliputi : gelas ukur, beaker glass $250 \mathrm{~mL}$, termometer, neraca analitik, oven, hotplate, labu ukur, magnetic stirer, elemeyer, corong pisah, , blender, spatula, pengaduk,pipet tetes,pipet volum. Alat pembuatan bubuk kopi: saring, baskom, blender, mortal, dan loyang atau plat plastik.

Bahan yang digunakan pada percobaan ini adalah Kopi lanang bubuk, kulit biji kopi, $\mathrm{Na}_{2} \mathrm{Co}_{3}$,Kloroform, Aguades,larutan kanji indikator. Bahan Standarisasi sebagai berikut: $\mathrm{KIO}_{3}, \mathrm{KI} 20 \%, \mathrm{HCl}$.

\section{Metodologi Penelitian}

Timbang larutan $\mathrm{KIO}_{3}$ 0,025 - 0,05 gr tambahkan 25 aquades kocok hingga tercampur, tambahkan $5 \mathrm{~mL}$ KI $20 \%$ dan 1,25 mL HCl pekat selanjutnya titrasi dangan larutan $\mathrm{Na}_{2} \mathrm{~S}_{2} \mathrm{O}_{3}$ dan tambahkan indikator kanji 2 tetes dam titrasi kembali denga larutan $\mathrm{Na}_{2} \mathrm{~S}_{2} \mathrm{O}_{3}$ hingga warna larutan menjadi bening.

Kopi lanang yang mempunyai kematangan yang pas yang kulitnya mudah dikupas, kemudian jemur diterik panas matahari atau oven sampai kering, kopi disangrai dan ditumbuk sampai halus.Kulit biji kopi juga dijemur sampai kering bila kulit kopi masih basah maka akan dilanjutkan pengovenan dan ditumbuk hingga halus. 
Kulit kopi yang sudah dikeringkan dan dihaluskan ditambahkan dengan beberapa variasi massa yaitu 5;10;15;20;25\% (m/m) terhadap bubuk kopi lanang. Setiap variasi komposisi kulit kopi ditambahkan $100 \mathrm{~mL}$ air dengan suhu seduh $100^{\circ} \mathrm{C}$. selanjutnya larutan kopi seduh di diamkan pada suhu ruang hingga mencapai suhu $30^{\circ} \mathrm{C}$ dan disaring

Ambil $20 \mathrm{ml}$ hasil filtrate kopi tambahkan $\mathrm{Na}_{2} \mathrm{CO}_{3}$ lalu dipanaskan dan dinginkan kembali,lalu masukkan kedalam corong pisah,ekstrak dengan kloroform berturut-turut $25 \mathrm{ml}$ sebanyak 2 kali,filtrate ditampung dalam elenmeyer kemudian diuapkan hingga menjadi serbuk kafein, dan larutkan pada $25 \mathrm{ml}$ akuades, dari larutan tersebuat ambil $5 \mathrm{ml}$ dan encerkan kembali ke $50 \mathrm{ml}$ larutan akuades. $20 \mathrm{ml}$ dari larutan tersebut masukkan pada labu takar $100 \mathrm{ml}$ tambahkan $25 \mathrm{ml}$ alkohol, $5 \mathrm{ml} \mathrm{H}_{2} \mathrm{So}_{4}$ 10\%,20 ml KI 0,1 $\mathrm{N}$ dan akuades hingga tanda batas, kemudian kocok hingga homogen. Ambil $20 \mathrm{ml}$ campuran tersebut dan titrasi dengan $\mathrm{Na}_{2} \mathrm{~S}_{2} \mathrm{O}_{3}$ dan tambahkan larutan kanji 2 tetes dan titrasi kembali dengan $\mathrm{Na}_{2} \mathrm{~S}_{2} \mathrm{O}_{3}$ hingga terjadi perubahan warna.

Setelah didapatkan penambahan massa kulit kopi yang optimum, maka variasi yang selanjutnya adalah menentukan suhu seduh pelarut dengan variasi $\left(60 ; 70 ; 80 ; 90 ; 100{ }^{0} \mathrm{C}\right)$. Kulit kopi optimum ditambahkan air $100 \mathrm{~mL}$ dengan variasi suhu $\left(60 ; 70 ; 80 ; 90 ; 100{ }^{0} \mathrm{C}\right)$. Selanjutnya larutan kopi seduh didiamkan pada suhu ruang hingga mencapai suhu $30^{\circ} \mathrm{C}$ dan disaring selanjutnya Ambil $20 \mathrm{ml}$ hasil filtrate kopi tambahkan $\mathrm{Na}_{2} \mathrm{CO}_{3}$ lalu dipanaskan dan dinginkan kembali,lalu masukkan kedalam corong pisah,ekstrak dengan kloroform berturut-turut $25 \mathrm{ml}$ sebanyak 2 kali,filtrate ditampung dalam elenmeyer kemudian diuapkan hingga menjadi serbuk kafein, dan larutkan pada $25 \mathrm{ml}$ akuades, dari larutan tersebuat ambil $5 \mathrm{ml}$ dan encerkan kembali ke $50 \mathrm{ml}$ larutan akuades. $20 \mathrm{ml}$ dari larutan tersebut masukkan pada labu takar $100 \mathrm{ml}$ tambahkan $25 \mathrm{ml}$ alkohol, $5 \mathrm{ml} \mathrm{H}_{2} \mathrm{So}_{4}$ 10\%,20 $\mathrm{ml} \mathrm{KI} \mathrm{0,1} \mathrm{N}$ dan akuades hingga tanda batas, kemudian kocok hingga homogen. Ambil $20 \mathrm{ml}$ campuran tersebut dan titrasi dengan $\mathrm{Na}_{2} \mathrm{~S}_{2} \mathrm{O}_{3}$ dan tambahkan larutan kanji 2 tetes dan titrasi kembali dengan $\mathrm{Na}_{2} \mathrm{~S}_{2} \mathrm{O}_{3}$ hingga terjadi perubahan warna.

\section{PEMBAHASAN}

Bahan utama yang digunakan dalam penelitian ini adalahkopi lanang (pearry coffee) dan kulit biji kopi. Kopi yang mempunyai kematangan yang baik di pisahkan dari kulitnya dan dijemur atau dioven hingga kering, sangrai kopi hingga berwarna hitam kecoklatandan tumbuk hingga halus. Kulit biji kopi yang sudah dicuci dikeringkan diterik matahari atau dioven dan 
tumbuk hingga halus.Proses pengeringan ini bertujuan untuk mengurangi kadar air yang terkandung dalam kulit kopi.

Pada proses standarisasi Natrium Theosulfat yang dilakukan adalah menimbang $\mathrm{KIO}_{3}$ 0,025 - 0,05 gr dan diencerkan ke $25 \mathrm{~mL}$ akuades kocok hingga tercampur. 1,25 mL $\mathrm{HCl}$ pekat dan $5 \mathrm{~mL}$ KI $20 \%$ dibebaskan melalui titrasi natrium theosulfat dengan menggunakan indikator kanji.

Untuk volume titrasi yang dihasilkan pada proses standarisasi ini yaitu berubahnya warna dari kuning hingga menjadi bening. Larutan standart yang digunakan dalam kebanyakan proses titrasi adalah natrium thiosulfat, garam ini biasanya tersedia sebagai pentahidrat $\mathrm{Na}_{2} \mathrm{~S}_{2} \mathrm{O}_{3} 5 \mathrm{H}_{2} \mathrm{O}$ larutan tidak boleh di standarisasi dengan penimbangan secara langsung, tetapi harus distandarisasi terhadap standar primer, dalam penelitian ini menggunakan $\mathrm{KIO}_{3}$ sebagai standar primer karena larutan natrium thiosulfat tidak stabil untuk waktu yang lama.

Fungsi penambahan padatan kalium iodide ini untuk memperbesar kelarutan iodium yang sukar larut dalam air dan kalium iodide ini untuk mereduksi analit hingga bisa dijadiakan standarisasi. Kemudian ditambahkan larutan asam klorida pekat karena titrasi ini dilakukan dalam suasana asam $(\mathrm{pH}<8,0)$ disebabkan karena larutan yang terdiri dari kalium iodat dan kalium iodida dalam kondisi netral atau memiliki keasaman rendah.

Penambahan KI dilakukan karena iodium sukar larut dalam air namun agak larut dalam larutan yang mengandung ion iodida sehingga akan membentuk senyawa kompleks tri iodida dengan iodide, KI berlebih juga ditambahkan untuk meningkatkan kelarutan dan mengurangi penguapan iodium. Hal ini dikarenakan titik penguapan I2 lebih kecil dibandingkan dengan KI maupun senyawa kompleks lain iodin.

Analis kafein didilakukan setelah diperoleh serbuk kulit biji kopi dengan variasi massa yaitu 5;10;15;20;25\% (m/m) terhadap 25 gram bubuk kopi. Campulan tersebut dilarutkan pada aquades $100 \mathrm{~mL}$ dan Suhu seduh $100{ }^{\circ} \mathrm{C}$.Campuran tersebut disaring menggunakan kertas saring untuk memisahkan ampasnya.Hasil filtrat dari yang telah didapat kemudian dilakukan pencampuran dengan 2 gram.Natrium karbonat $\left(\mathrm{Na}_{2} \mathrm{CO}_{3}\right)$ dipanaskan hingga terlarut.Hasil pencampuran tersebut diektrak menggunakan $25 \mathrm{~mL}$ pelarut kloroform sebanyak 2 kali.Hasil ektrak dititrasi menggunakan Natrium Theosulfat. 


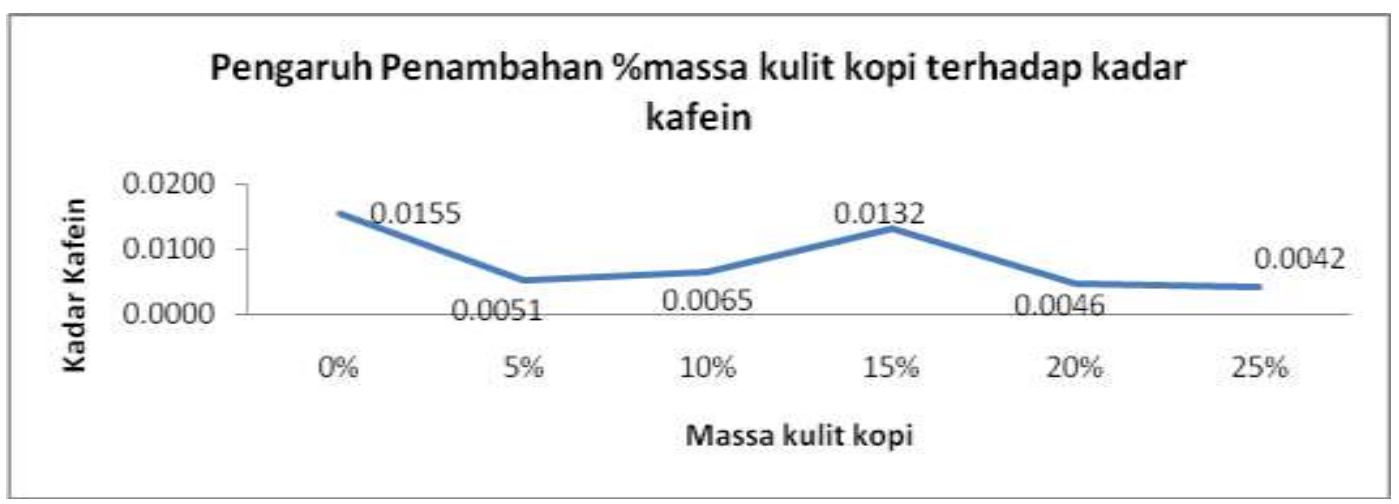

Gambar 4.3.1 Grafik Pengaruh Massa Penambahan Kulit biji kopi Terhadap kopi Lanang (peaberry caffea).

Hasil dari penelitian ini menunjukkan bahwa uji kandungan kafein pada kopi menggunakan metode titrasi Natrium Theosulfat. Ekstrak klorofom dari 25 gram kopi dan penambahan 5\% kulit kopi menunjukkan bahwa 30,0mL penambahan natrium theosulfat dan terjadi perubahan warana dan kadar kafein 0,0051. Pada 10\% kulit kopi penambahan natrium theosulfat 33,6 mL dan kadar kafein 0,0065, namun pada $15 \%$ kulit kopi penambahan natrium theosulfat yaitu 68,2 mL dan kadar kafein 0,0132 menunjukan bahawa pada penambahan 15\% kopi kafein yang turun lebih sedikit dari $10 \%$ karena pada saat preparasi sampel suhu seduh kurang maksimal. pada $20 \%$ dan $25 \%$ penambahan kulit kopi warna sampel saat dititrasi dengan natrium theosulfat cepat berubah warna bening hal ini dikarenakan bahwa kulit biji dapat menurunkan kadar kafein karena mengandung senyawa antioksidan dengan kadar kafein 0,0042. Kadar kafein 25 gram kopi lanang tanpa pembahan kulit kopi adalah 0,0155 yang artinya dari hasil penelitian pembahan kulit kopi menurunkan kadar kafein.

Pemisahan kafein dari kopi bubuk dilakukan dengan metode ektraksi.Proses ekstraksi, pertama dilakukan penyeduhan dengan air mendidih sebanyak $100 \mathrm{ml}$, karena menurut Wilson \& Gisvold (1982) dalam Fitri, 2008), kafein larut dalam 1,5 bagian air mendidih. Diharapkan kafein yang terlarut dapat mencapai jumlah optimum.Hasilnya kemudian dilakukan penyaringan, filtrate kemudian ditambahkan $\mathrm{Na}_{2} \mathrm{CO}_{3}$, penggunaan $\mathrm{Na}_{2} \mathrm{CO}_{3}$ untuk mengikat tanin yang terlarut. Setelah itu dipekatkan dengan cara dipanaskan sampai setengahnya dan didinginkan.

Langkah selanjutnya dilakukan ekstraksi dengan menggunakan $25 \mathrm{ml}$ pelarut kloroform sebanyak dua kali dalam corong pisah, pemilihan pelarut kloroform karena kafein mudah larut dalam kloroform (Depkes, 1995), dan menurut Wilson dan Gisvold (1982) dalam Fitri, (2008), kafein larut dalam 6 bagian kloroform. Menurut Djajanegara (2009) dinyatakan bahwa,kloroform dapat melarutkan senyawa alkaloid. Kafein merupakan alkaloid, maka dengan penambahan 
kloroform akan memudahkan pelarutan kafein. Untuk ekstraksi kafein dapat juga digunakan pelarut benzen dan etil asetat, namun karena beberapa pertimbangan seperti harga, toksisitas, dan kelarutan, maka kloroform lebih aman dan murah untuk digunakan, selain karena memiliki titik didih yang rendah (Soraya, 2008).

Sebanyak $25 \mathrm{ml}$ kloroform dimasukkan ke dalam corong pisah, dikocok, dan terjadi dua lapisan, lapisan bawah yang merupakan lapisan kloroform yang mengandung kafein dikeluarkan dan ditampung.Larutan kafein diuapkan pelarutnya dengan menggunakan alat pemanas atau hotplate.

Serbuk kafein yang diperoleh dilarutkan dalam $50 \mathrm{~mL}$ akuades.Ambil $20 \mathrm{~mL}$ dari larutan tersebut dan titrasi menggunakan Natrium theosulfat dan tambahkan 2 tetes Larutan kanji titrasi kembali dengan Natrium theosulfat hingga terjadi perubahan warna.Sehingga kandungan kadar kafein terlihat dari banyaknya titran yang di campurkan. Apabila penambahan titran dengan volume yang paling rendah maka kandungan kadar kafein turun. Hasil dari penentuan kadar kafein kopi tanpa kulit volume titrannya $82 \mathrm{~mL}$ dan kadar kafeinnya adalah 0,0155\%.

Analisis kafein dilakukan setelah diperoleh penambahan kulit kopi optimum dan variasi suhu seduh pelarut $\left(60 ; 70 ; 80 ; 90 ; 100{ }^{0} \mathrm{C}\right)$.terhadap 25 gram bubuk kopi. Campulan tersebut dilarutkan pada aquades $100 \mathrm{~mL}$ dan variasi suhu seduh.Campuran tersebut di saring menggunakan kertas saring untuk memisahkan ampasnya. Hasil filtrat dari yang telah didapat kemudian dilakukan pencampuran dengan 2 gram Natrium karbonat $\left(\mathrm{Na}_{2} \mathrm{CO}_{3}\right)$ dipanaskan hingga terlarut. Hasil pencampuran tersebut diektrak menggunakan $25 \mathrm{~mL}$ pelarut kloroform sebanyak 2 kali.Hasil ektrak di titrasi menggunakan Natrium Theosulfat.

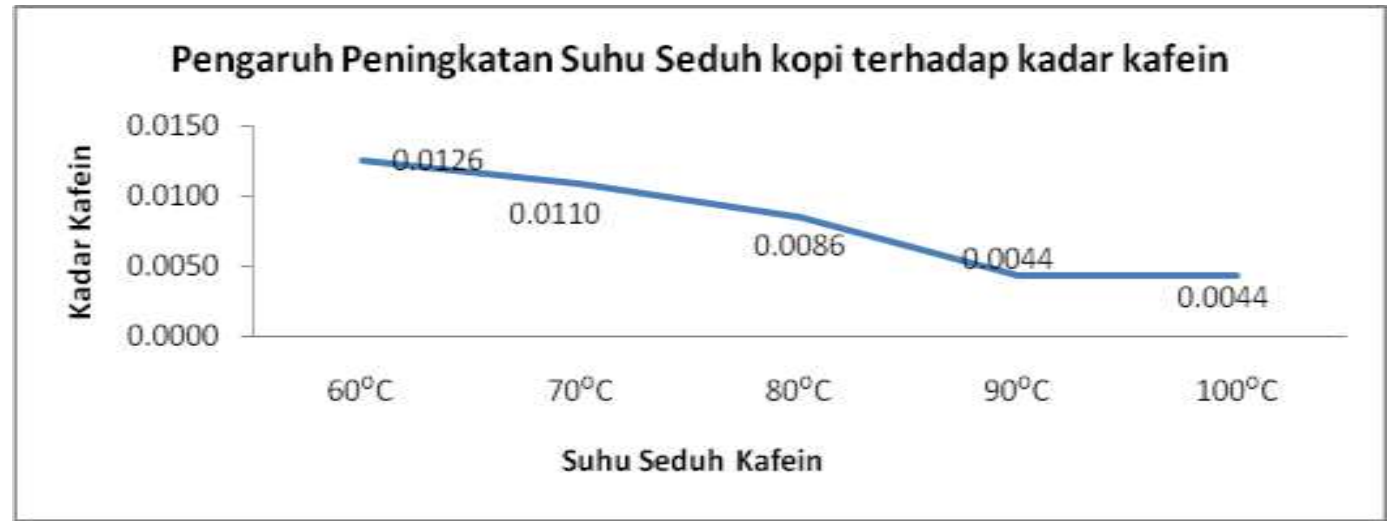

Gambar 4.3.2 Grafik Pengaruh Suhu Seduh Kopi Terhadap kopi Lanang (peaberry caffea).

Berdasarkan hasil analisis kadar kafein dengan variasi suhu seduh, kandungan kafein pada kopi ditunjukkan pada tabel 4.3 yakni diperoleh penurunan kadar kafein paling banyak terdapat pada suhu seduh pelarut $90{ }^{0} \mathrm{C}-96{ }^{0} \mathrm{C}$, kadar kafein pada suhu tersebut adalah 0,0044 , pada 60 
${ }^{0} \mathrm{C}$ kadar kafein 0,0126, kadar kafein pada suhu $70{ }^{0} \mathrm{C}$ adalah 0,0110 dan kadar kafein pada suhu $80{ }^{0} \mathrm{C}$ adalah 0,0086 .

Menurut National Coffee Association suhu air paling baik dalam membuat kopi ideanya adalah $195^{\circ} \mathrm{F}$ sampai $205^{\circ} \mathrm{F}$ atau 90 - 96 derajat celcius. Tapi beberapa orang biasanya menggunakan suhu di bawah 90 derajat Celsius saat menyeduh dengan metode manual brew. Semuanya lagi-lagi dikembalikan kepada selera masing-masing. Yang jelas suhu tidak pernah di atas 96 derajat Celsius karena akan membuat kopi terasa pahit dan flavor pada kopi bisa saja hilang.

Hasil uji kandungan kadar kafein pada kopi dengan penambahan kulit kopi dengan menggunakan metode Titrasi Natrium ThioSulfat. Dari hasil titrasi menunjukkan bahwa penambahan kulit kopi dapat menurunkan kadar kafein.

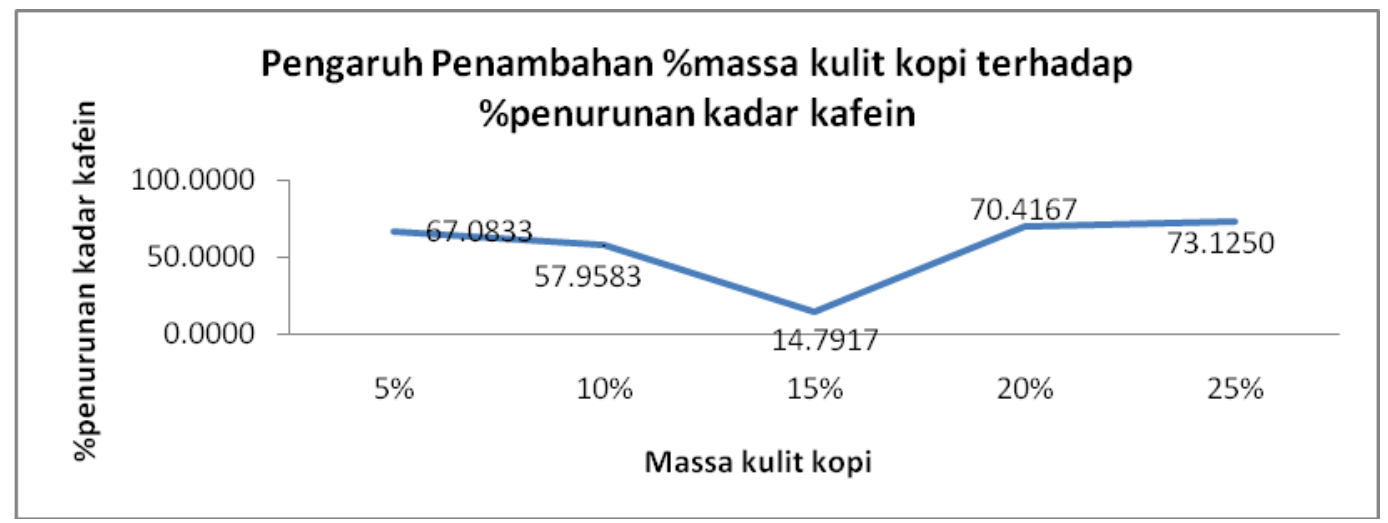

Gambar 4.3.3 Grafik Pengaruh Penambahan \% Massa Kulit biji kopi Terhadap\%Penurunan kadar kafein pada kopi Lanang (peaberry caffea).

Berdasarkan dari hasil analisis kandungan kafein pengaruh penambahan \%massa kulit kopi terhadap \% penurunan kadar kafein ditunjukkan dalam tabel. Penurunan kadar kafein paling tinggi pada penambahan 25\% kulit kopi terhadap 25 gram kopi lanang yaitu 73,1250\%,pada penambahan $10 \%$ kulit kopi kadar kafein turun 57,9583\%, pada penambahan $20 \%$ kulit kopi terhadap kopi lanang turun 70,4167\%sedangkan pada penambahan 15\% kulit kopi terhadap kopi lanang hanya turun $14,7917 \%$ dikarenakan pada saat memanaskan pelarut tidak maksimal pada penelitian ini suhu seduh sangat mempengaruhi penurunan kadar kafein.

Perubahan sifat fisik dan kimia terjadi selama proses penyangraian, menurut Ukersdan Prescott dalam Ciptadi dan Nasution (1985) seperti swelling, penguapan air, terbentuknya senyawa volatile, karmelisasi karbohidrat, pengurangan serat kasar, denaturasi protein, terbentuknya gas $\mathrm{CO}_{2}$ yang mengisi pori-pori kopi. Semakin tingginya suhu dan lama penyangraian menyebabkan terjadinya pirolisis senyawa asam sehingga senyawa ini 
menguap.Rasa asam yang terdapat pada kopi tercipta dari kandungan asam yang ada dalam kopi, yang dimana standar rasa kopi berdasarkan SNI.01-2983-1992 adalah normal, itu berarti nilai pH yang terkandung pada kopi harus netral yakni nilai $\mathrm{pH}$ sama dengan 7.Pada percobaan kali sebelum larutan kopi di uji pH meter di Kalibrasi menggunakan pH 4,pH7 dan pH 10 agar hasil nya lebih akurat. Kopi selain menjadi minuman yang identik dengan rasa pahit, juga identik dengan rasa asam. Itulah yang menyebabkan beberapa orang enggan meminum kopi karena takut rasa asam akan memengaruhi kesehatan mereka. Padahal tingkat keasaman pada kopi hanya berada di level pH 5. Artinya keasaman pada kopi masih aman dikonsumsi. Selain itu tingkat keasaman kopi juga masih jauh di bawah bir, jus jeruk bahkan soda.Hasil dari penelitian ini $\mathrm{pH}$ yang terkandung dalam 25 gram kopi dengan penambahan 25\% kulit kopi adalah 5,5 yang artinya kopi dengan penambahan kulit kopi masih aman untuk dikonsumsi.

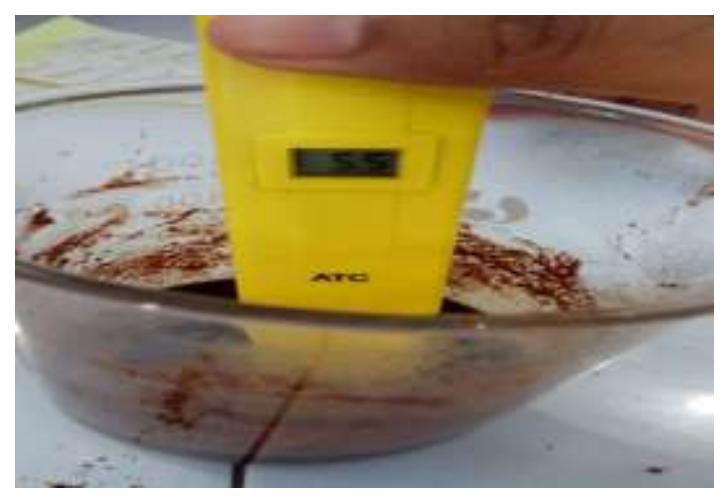

Gambar 4.4.1 Uji Tingkat Keasaman pada Kopi.

Pemprosesan kopi sebelum dapat diminum melalui proses panjang yaitu dari pemanenan biji kopi yang telah matang baik dengan cara mesin maupun dengan tangankemudian dilakukan pemrosesan biji kopi dan pengeringan sebelum menjadi kopi gelondong. Setelah penyangraian biji kopi digiling atau dihaluskan menjadi bubuk kopi sebelum kopi dapat diminum.Rasa,Aroma dan warna pada kopi terkantung pada cara pengolahannya seperti penyangraian dan suhu seduh pelarut yang digunakan.

Hasil dari penelitian ini uji rasa,aroma dan warna dari 10 panelis,Panelis pertama yaitu sujak pranoto beliau mengatakan bahwa rasa dari kopi tersebut masi sama dengan rasa kopi tanpa penambahan kulit kopi dan memberikan nilai 9, dan aromanya juga sama dengan kopi tanpa kulitdan memberikan nilai 9 dan warna kopi coklat muda dengan memberikan nilai 9. Panelis kedua yaitu Fakih Wahyu beliau mengatakan bahwa rasa dari kopi tersebut masi sama dengan rasa kopi tanpa penambahan kulit kopi dan memberikan nilai 9, dan aromanya juga sama dengan 
kopi tanpa kulitdan memberikan nilai 9 dan warna kopi coklat muda dengan memberikan nilai 8. Panelis ketiga yaitu Feri Ilsya Hidayullah mengatakan bahwa rasa dari kopi tersebut masi sama dengan rasa kopi tanpa penambahan kulit kopi dan memberikan nilai 9, dan aromanya juga sama dengan kopi tanpa kulitdan memberikan nilai 8 dan warna kopi coklat muda dengan memberikan nilai 8. 10 Panelis mengatakan bahwa kopi dengan penambahan kulit rasanya sama dengan kopi tanpa penambahan kulit.1 panelis menilai kopi tersebut rasanya kurang pas dan masi ada sedikit rasa kulit kopi dan kopi sangat kental itu dikarenakan panelis ini tidak suka dengan kopi yang kental dan seleranya kopi yang massanya sedikit. Kopi yang sering dikonsumsi oleh panelis kebanyakan kopi yang instan atau kopi sasetan yang langsung diseduh tanpa penambahan bahan lain sedikitpun. Penambahan kulit kopi kering pada kopi ini bertujuan untuk menurunkan kadar kafein pada kopi tersebut, selain itu juga bertujuan agar penikmat kopi yang mempunyai kelainan tertentu seperti menderita penyakit ginjal dapat juga menikmati kopi yang berkadar kafein rendah tersebut tanpa harus takut resikonya.

\section{Kesimpulan Dan Saran}

Dari hasil penelitian yang diperoleh dapat disimpulkan sebagai berikut :

Penambahan massa kulit kopi sangat mempengaruhi penurunan kadar kafein. Penambahan 25\% kulit kopi terhadap 25 gram kopi lanang dengan kadar kafein 0,0042 di uji dengan metode titrasi. Suhu seduh pelarut sangat mempengaruhi penurunan kadar kafein. Suhu seduh yang optimum pada pembuatan kopi adalah $90-96{ }^{0} \mathrm{C}$ dengan kadar kafein 0,0044 dengan metode titrasi

\section{DAFTAR PUSTAKA}

Dewi, Ni Wayan Octarini A.C, et al. 2014.Aktivitas Antioksidan Senyawa Flavonoid Ekstrak Etanol Biji Terong Belanda (SolanumBetaceum, Syn) Dalam Menghambat Reaksi Peroksidasi LemakPada Plasma Darah Tikus Wistar. Denpasar : Universitas Udayana dalam jurnal Cakra Kimia (Indonesian E-Journal of Applied Chemistry), Vol. 2, No. 1, Mei 2014 Handayani, Sri.2014.

Kandungan Kimia Beberapa Tanaman Dan Kulit Buah Berwarna Serta Manfaatnya Bagi Kesehatan.Yogyakarta : Universitas Negeri Yogyakarta. Harborne, J B. 1987. Metode Fitokimia. Bandung : Penerbit ITB.

Waji, Resi Agestia, Andis Sugrani. 2009. Makalah Kimia Organik Bahan Alam : Flavonoid (Qurcetin).Makassar : Universitas Hasannudin Makassar

Arief, Bustomi, Ahmad Zaki Zulfikar.2014.“Analisis Distribusi Intensitas RGB Citra Digital untuk Klasifikasi Kualitas Biji Jagung menggunakan Jaringan Syaraf Tiruan.” Surabaya : 
Institut Sepuluh Nopember (ITS) JURNAL FISIKA DAN APLIKASINYA, Vol. 10, No. 3,Oktober 2014

Li Chen Wu, Hsiu-Wen Hsu, Yun-Chen Chen, Chih-Chung Chiu, Yu-In Lin and Annie Ho . 2005. Antioxidant AndAntiproliferative ActivitiesOf Red Aris. 2013. Teori Ekonomi Produksi. Jakarta: Diandra Primamitra

Assauri, Sofjan. 2004. Manajemen Produksi dan Operasi. Edisi revisi 2004. Jakarta: Lembaga Penerbit Fakultas Ekonomi Universitas Indonesia.

Galih, Ambar puspa \& Setiawina, N.Djinar. 2014. Analisis Pengaruh Jumlah Produksi, Luas Lahan dan Kurs Dollar Terhadap Volume Ekspor Kopi Indonesia. Periode Tahun 20012011. E-Jurnal Ekonomi Pembangunan Vol. 3, No. 2. Universitas Udayana.

Purba, Rea Efraim. 2011. Analisis Ekspor Kopi Indonesia ke Amerika dan Faktor- faktor yang Mempengaruhinya. Skripsi. Universitas Diponegoro.

Anonim., (2009), Manfaat dan Bahaya Kandungan Kafein dalam Kopi. Diakses dari: http://www.azk4/2009/02/Manfaat-dan-bahaya-kopi.html pada tanggal 10 Maret 2014.Medan.

Armansyah,M.,(2010), Mempelajari Minuman Formulasi dari Kombinasi Bubuk Kakao dengan Jahe Instan, Teknologi Pertanian, Universitas Hasanuddin, Makassar

Clarke,R.J. and Macrae,R.,(1987), Coffee Technology (Volume 2), Elsevier Applied Science, London and New York. Journal Beverages Journal, Page. 149 - 175.

Davia.D.,Gary, Kris G.Z.,(1982), “Organic Labortory Techniques. A Contemporary Approach”. Second Edition, Sounder Collage Publishing, Washington, 55-60.

Farida, Ana.,Ristanti,E., Kumoro, A.C.Dr, S.T.,M.T., (2013), penurunan Kadar kafein Dan Asam Total Pada Biji Kopi Robusta Menggunakan Teknologi Fermentasi Anaerob Fakultatif Dengan Mikroba Nopkor MZ-15, Teknik Kimia dan Industri,Universitas Diponegoro, Semarang. Jurnal Teknologi kimia dan Industri, Vol.2, No.3, 2013, Halaman:70-75. 